\title{
HIGH-TEMPERATURE OXIDATION OF FOUR HOT-WORK TOOL STEELS
}

\author{
VISOKOTEMPERATURNA OKSIDACIJA ŠTIRIH ORODNIH JEKEL \\ ZA DELO V VROČEM
}

\author{
Tilen Balaško ${ }^{1}$, Jaka Burja ${ }^{2}$, Jožef Medved ${ }^{1}$ \\ ${ }^{1}$ University of Ljubljana, Faculty of Natural Sciences and Engineering, Aškerčeva cesta 12, 1000 Ljubljana, Slovenia \\ 2Institute of Metals and Technology, Lepi pot 11, 1000 Ljubljana, Slovenia \\ tilen.balasko@omm.ntf.uni-lj.si
}

Prejem rokopisa - received: 2018-05-25; sprejem za objavo - accepted for publication: 2018-06-28

doi:10.17222/mit.2018.107

\begin{abstract}
Hot-work tool steels have very good mechanical properties, especially strength, hardness and wear resistance at high temperatures. Therefore, hot-work tool steels are used for different applications, such as the high-pressure die casting of light alloys, the extrusion of polymers and forging. Since all these processes are operating at high temperatures, the main focus of this research was to investigate the high-temperature oxidation resistance of tool steels. We investigated the high-temperature oxidation at two different temperatures: $500{ }^{\circ} \mathrm{C}$ and $700{ }^{\circ} \mathrm{C}$. The following tool steels were analyzed: HTCS-130, W600, RavnexHD and Dievar. Tests were made in an air atmosphere, while the heating and cooling were made in a controlled argon atmosphere. Simultaneous thermal analysis (STA 449 C Jupiter), scanning electron microscopy (SEM and EDS) and X-ray diffraction were used as the investigation methods. The results showed that during high-temperature oxidation at $500{ }^{\circ} \mathrm{C} \mathrm{Dievar}$ steel has the best oxidation resistance, followed by RavnexHD, HTCS-130 and W600. However, at $700{ }^{\circ} \mathrm{C}$ the results were different, HTCS-130 had the best oxidation resistance, followed by Dievar, W600 and RavnexHD.

Keywords: tool steels, oxidation, simultaneous thermal analysis (STA), X-ray diffraction (XRD)
\end{abstract}

Orodna jekla za delo v vročem imajo zelo dobre mehanske lastnosti, med katerimi so najpomembnejše trdnost, trdota in obrabna obstojnost pri visokih temperaturah. Uporabna so predvsem za izdelavo orodij za tlačno litje lahkih kovin, ekstruzijo polimerov in utopno kovanje. Ker vsi ti procesi potekajo pri visokih temperaturah, je bil namen raziskave ugotavljanje korozijske obstojnosti preiskovanih jekel pri visokih temperaturah. Visokotemperaturno oksidacijo smo preiskovali pri dveh temperaturah: $500{ }^{\circ} \mathrm{C}$ in $700{ }^{\circ} \mathrm{C}$. Analizirali smo naslednja orodna jekla: HTCS-130, W600, RavnexHD in Dievar. Preizkusi so potekali v kontrolirani atmosferi zraka, medtem ko sta segrevanje in ohlajanje potekala v zaščitni atmosferi argona. Uporabili smo napravo za simultano termično analizo (STA 449 C Jupiter), nato pa smo vzorce analizirali še s pomočjo vrstične elektronske mikroskopije (SEM in EDS), ter rentgenske difrakcije (XRD). Rezultati so pokazali, da je pri temperaturi oksidacije $500{ }^{\circ} \mathrm{C}$ korozijsko najbolj obstojno jeklo Dievar, sledijo RavnexHD, HTCS-130 in W600. Pri temperaturi oksidacije $700{ }^{\circ} \mathrm{C}$ pa je korozijsko najbolj obstojno jeklo HTCS-130, sledijo Dievar, W600 in RavnexHD.

Ključne besede: orodna jekla, oksidacija, simultana termična analiza (STA), rentgenska difrakcija (XRD)

\section{INTRODUCTION}

Hot-work tool steels are commonly used for highpressure, die-casting molds. With every casting cycle, the mold is heated up and then cooled down, which means the surface begins to slowly oxidize. ${ }^{1}$ Since these steels are used at high temperatures, we decided to study the influence of the different chemical compositions of the investigated steels on the high-temperature oxidation. The main reason for the research of this topic is the scarcity of similar investigations. Understanding the nature of oxidation is very important for a die life-span evaluation.

The high-temperature oxidation of iron is stable under isothermal conditions for long periods of time and usually follows the parabolic rate law. ${ }^{2}$ Oxidation between $700{ }^{\circ} \mathrm{C}$ and $1250{ }^{\circ} \mathrm{C}$ follows the parabolic-oxidation regime and develops three layers: an outermost thin hematite layer $\left(\mathrm{Fe}_{2} \mathrm{O}_{3}\right)$, a thin intermediate magnetite layer $\left(\mathrm{Fe}_{3} \mathrm{O}_{4}\right)$, and a thick inner wüstite layer $(\mathrm{FeO}){ }^{3}$ The thickness of every layer reflects the diffusion rate of the
Fe in it. The Fe diffusion in wüstite is much greater than in hematite and magnetite. ${ }^{4}$ On the other hand, the high-temperature oxidation of steels is much more complex. The main reason is the presence of impurities and alloying elements in the steels that affect the oxidation process. ${ }^{2}$ The oxidation rate grows with the temperature, and at $570{ }^{\circ} \mathrm{C}$ the oxidation becomes very rapid. Above that temperature, we should have three oxide layers: $\mathrm{FeO}, \mathrm{Fe}_{3} \mathrm{O}_{4}$ and $\mathrm{Fe}_{2} \mathrm{O}_{3}$. $\mathrm{FeO}$ is thermodynamically unstable under $570{ }^{\circ} \mathrm{C} .5$

The influence of alloying elements on the kinetics of the high-temperature oxidation of hot-work tool steels should be considered. Molybdenum can improve the oxidation of steel up to $900{ }^{\circ} \mathrm{C}$ for $10 \mathrm{~h}$, but it has a catastrophic influence after $10 \mathrm{~h}$ and above $900{ }^{\circ} \mathrm{C} .{ }^{6}$ High Mo steels are prone to segregations and the formation of intermetallic phases such as $\sigma, \gamma$ and Laves phases above $900{ }^{\circ} \mathrm{C}$, which lower the oxidation resistance and make them vulnerable to cracking during hot working. ${ }^{6-9}$ Steels with higher Mo content typically face 
Table 1: Chemical composition for the investigated steels in mass fractions

\begin{tabular}{|c|c|c|c|c|c|c|c|c|c|c|c|c|}
\hline \multirow{2}{*}{ Steel } & \multicolumn{12}{|c|}{ Chemical elements } \\
\hline & $\mathrm{C}$ & $\mathrm{Si}$ & $\mathrm{Mn}$ & $\mathrm{P}$ & $\mathrm{S}$ & $\mathrm{Cr}$ & $\mathrm{Ni}$ & $\mathrm{V}$ & W & $\mathrm{Cu}$ & Mo & $\mathrm{Fe}$ \\
\hline HTCS-130 & 0.31 & 0.07 & 0.08 & 0.007 & 0.001 & 0.1 & 0.04 & 0.01 & 1.9 & 0.04 & 3.2 & Bal. \\
\hline RavnexHD & 0.36 & 0.30 & 0.40 & $<0.01$ & 0.001 & 5.00 & 1.65 & 0.60 & $<0.01$ & $<0.01$ & 1.70 & Bal. \\
\hline W600 & 0.32 & 0.12 & 0.23 & 0.005 & 0.001 & 0.11 & 2.1 & $<0.01$ & 1.9 & 0.01 & 3.2 & Bal. \\
\hline Dievar & 0.34 & 0.17 & 0.44 & 0.008 & 0.001 & 5.05 & 0.19 & 0.54 & 0.01 & 0.08 & 2.37 & Bal. \\
\hline
\end{tabular}

oxidation complications above $900{ }^{\circ} \mathrm{C}$ due to $\mathrm{MoO}_{3}$ formation. ${ }^{10-12}$ Since we studied oxidation below $900{ }^{\circ} \mathrm{C}$ the Mo should improve the oxidation resistance.

The addition of $\mathrm{Ni}$ improves the high-temperature oxidation resistance of low-carbon high-strength steels. ${ }^{13-16}$ Fukugawa et al. indicate that Ni reduces the oxidation rate and promotes inner oxidation. ${ }^{13}$ Meanwhile, Si degrades the high-temperature oxidation resistance of steels with low amounts of $\mathrm{Cu}$ and $\mathrm{Ni} .{ }^{13,17}$ Silicon promotes inner oxidation and the formation of low-temperature-melting fayalite $\left(2 \mathrm{FeO} . \mathrm{SiO}_{2}\right) \cdot{ }^{13,18,19}$ Chromium is a well-known alloying element that increases resistance to high-temperature oxidation. There is a critical $\mathrm{Cr}$ concentration $(\sim 12 \mathrm{w} / \%)$ for the formation of a protective $\mathrm{Cr}_{2} \mathrm{O}_{3}$ surface layer. ${ }^{20}$ Small amounts of $\mathrm{Mn}$ can lower the critical $\mathrm{Cr}$ concentration. A thin compact oxide layer forms, mostly composed of $\mathrm{Mn}-\mathrm{Cr}$ spinels and Cr-rich oxides, which improve the high-temperature oxidation resistance. Therefore, Mn indirectly increases the high-temperature oxidation resistance..$^{20}$

\section{EXPERIMENTAL PART}

Four hot-work tool steels were investigated. The chemical compositions of the investigated steels are shown in Table 1. Samples with a diameter of $4 \mathrm{~mm}$ and a height of $1.75 \mathrm{~mm}$ were used with thermogravimetric analyses (TG). Because the results of the high-temperature oxidation are usually given in mass change after a certain time per specific surface of the sample examined the samples were grinded to a smooth surface. The thermogravimetric analysis was made in NETZSCH STA $449 \mathrm{C}$ Jupiter thermal analyzer. The samples were heated at $20 \mathrm{~K} / \mathrm{min}$ in a protective Ar atmosphere to the oxidation temperature, and then an air atmosphere was

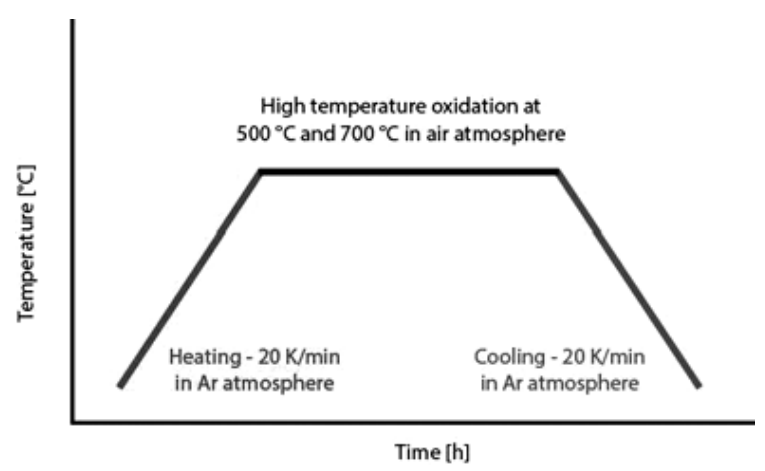

Figure 1: Schematic presentation of the oxidation process introduced. The samples were held at the temperature for $48 \mathrm{~h}$. The cooling was carried out in an argon atmosphere at $20 \mathrm{~K} / \mathrm{min}$ to room temperature. The oxidation was carried out at two different temperatures, i.e., $500{ }^{\circ} \mathrm{C}$ and $700{ }^{\circ} \mathrm{C}$. A schematic presentation of the oxidation process is shown in Figure 1.

After the oxidation the samples were metallographically prepared for scanning electron microscopy (SEM). We measured the thickness of the oxide layer for all the experimental samples with the SEM (JEOL JSM-5610). We also used EDS (Energy-dispersive X-ray spectroscopy) analysis to determine the composition of the oxide layer.

For the X-ray diffraction (XRD) studies larger samples $(20 \mathrm{~mm} \times 40 \mathrm{~mm} \times 10 \mathrm{~mm})$ were put into annealing furnaces heated to $500{ }^{\circ} \mathrm{C}$ and $700{ }^{\circ} \mathrm{C}$, and held at temperature for $48 \mathrm{~h}$ in an air atmosphere. We used a PANalytical 3040 X-ray Diffractometer for XRD analysis.

\section{RESULTS AND DISCUSSION}

\subsection{Thermogravimetry (TG)}

We investigated the mass change of the steel samples at the two different temperatures. The results of the thermogravimetric analyses for high-temperature oxidation at $500{ }^{\circ} \mathrm{C}$ are shown in Figure 2 and Table 2. W600 gained the most weight, i.e., $1.91 \mathrm{mg} / \mathrm{cm}^{2}$, which means it is the least resistant to high-temperature oxidation at $500{ }^{\circ} \mathrm{C}$. The second was HTCS-130, which gained $1.55 \mathrm{mg} / \mathrm{cm}^{2}$. RavnexHD was third, the mass gain was $1.33 \mathrm{mg} / \mathrm{cm}^{2}$. The most oxidation-resistant steel at $500{ }^{\circ} \mathrm{C}$ was Dievar, with a mass change of $0.96 \mathrm{mg} / \mathrm{cm}^{2}$. The parabolic law can describe all the oxidation rates of the investigated steels, and some parts are even linear (Figure 2). The reason why Dievar and RavnexHD are the most resistant to oxidation at $500{ }^{\circ} \mathrm{C}$ is the $\mathrm{Cr}$ content ( 5 w/\%). Chromium starts to form a protective $\mathrm{Cr}_{2} \mathrm{O}_{3}$ layer during high-temperature oxidation. ${ }^{21}$ Dievar has better resistance than RavnexHD, because of the higher Mo and the lower Ni and Si contents.

The results of the high-temperature oxidation at $700{ }^{\circ} \mathrm{C}$ are presented in Figure 3. The higher temperature and consequently higher diffusion rates of the elements give different results, as presented in Table 2. RavnexHD gained the most weight $\left(15.65 \mathrm{mg} / \mathrm{cm}^{2}\right)$, second was W600 (13.82 $\left.\mathrm{mg} / \mathrm{cm}^{2}\right)$, third was Dievar $\left(9.33 \mathrm{mg} / \mathrm{cm}^{2}\right)$, while the most oxidation-resistant steel at 


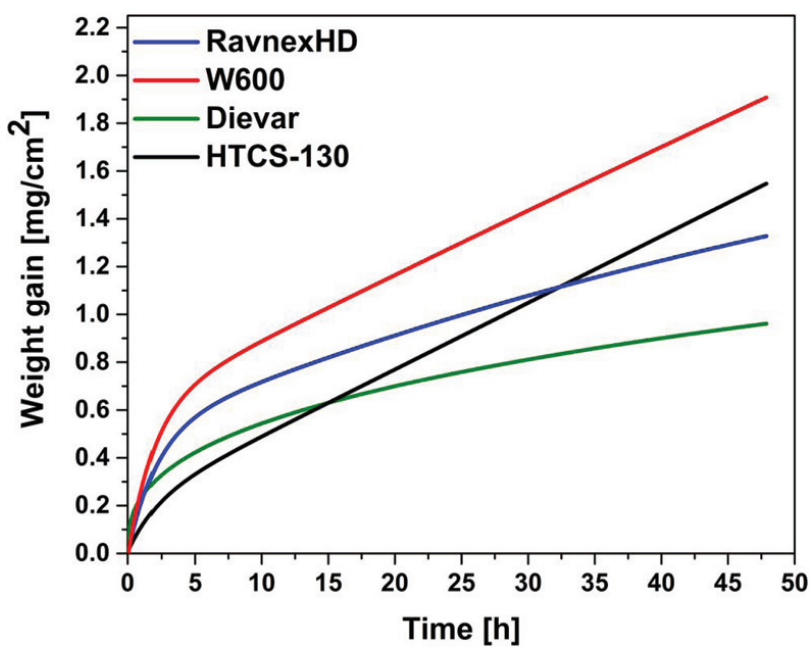

Figure 2: Mass change per specific surface depending on the time at $500{ }^{\circ} \mathrm{C}$

$700{ }^{\circ} \mathrm{C}$ was HTCS-130, with a mass change of $2.45 \mathrm{mg} / \mathrm{cm}^{2}$. The main reason is the ratio between the chemical elements. HTCS-130 has the lowest amount of $\mathrm{C}, \mathrm{Si}, \mathrm{Cr}, \mathrm{Ni}$ and $\mathrm{Mn}$, compared to the other investigated steels (Table 1). While the second steel, Dievar has high $\mathrm{Mo}, \mathrm{Cr}, \mathrm{Mn}$ and $\mathrm{V}$ content. The first three chemical elements give Dievar high-temperature oxidation resistance. Meanwhile, W600 and RavnexHD have the highest mass change; the reason is the combination of $\mathrm{Ni}$ and $\mathrm{Mo}$ (high $\mathrm{Ni}$ and $\mathrm{Mo}$ cause porous scale formation). ${ }^{22}$

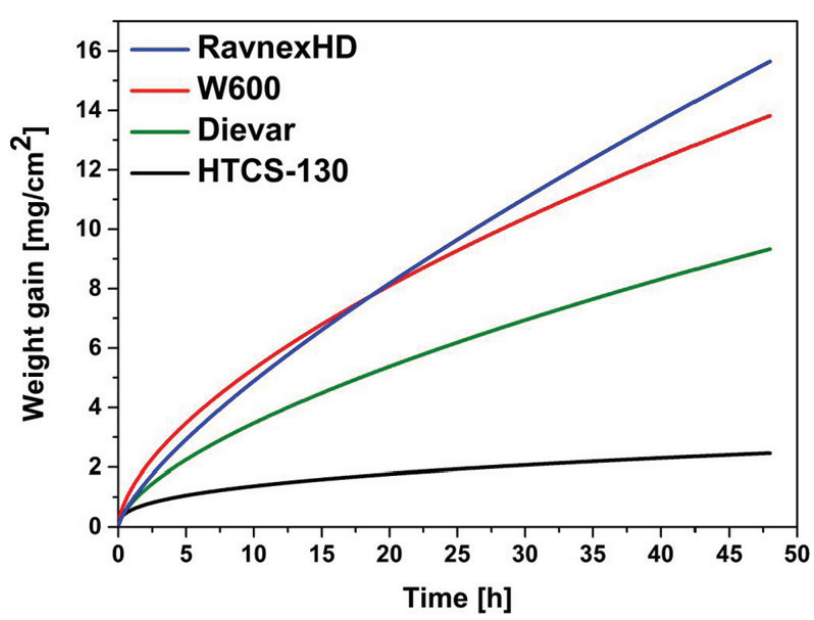

Figure 3: Mass change per specific surface depending on the time at $700{ }^{\circ} \mathrm{C}$

Table 2: Change in mass for investigated steels at investigated temperatures

\begin{tabular}{|l|c|c|}
\hline \multicolumn{1}{|c|}{ Steel } & $\begin{array}{c}\text { Average change in } \\
\text { mass at temperature of } \\
500{ }^{\circ} \mathrm{C}\left(\mathrm{mg} / \mathrm{cm}^{2}\right)\end{array}$ & $\begin{array}{c}\text { Average change in } \\
\text { mass at temperature of } \\
700^{\circ} \mathrm{C}\left(\mathrm{mg} / \mathrm{cm}^{2}\right)\end{array}$ \\
\hline HTCS-130 & 1.55 & 2.45 \\
\hline W600 & 1.91 & 13.82 \\
\hline RavnexHD & 1.33 & 15.65 \\
\hline Dievar & 0.96 & 9.33 \\
\hline
\end{tabular}
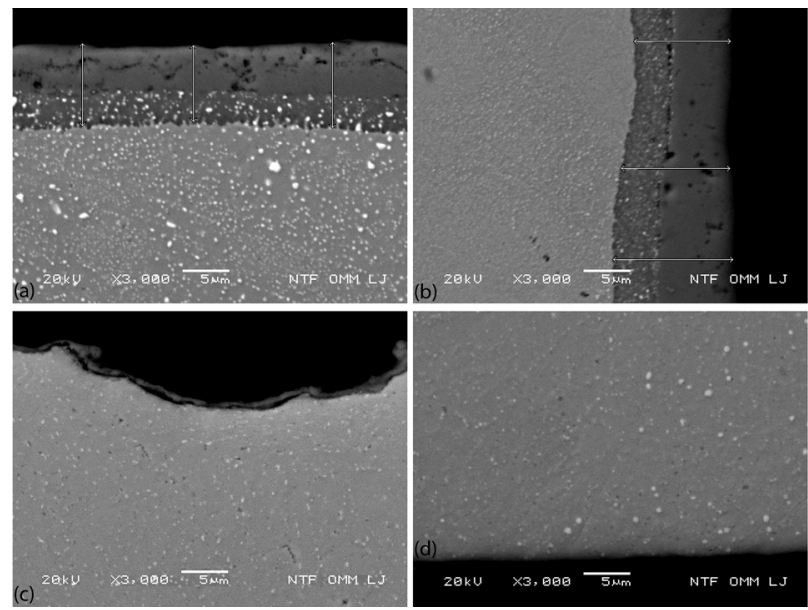

Figure 4: Thickness of the oxide layer at $500{ }^{\circ} \mathrm{C}$ of: a) HTCS-130, b) W600, c) RavnexHD and d) Dievar

RavnexHD has a lower oxidation resistance at $700{ }^{\circ} \mathrm{C}$ compared to W600, due to the lower Mo content.

\subsection{Scanning electron microscopy (SEM)}

The TG samples' oxide layers were analyzed with SEM. First, we measured the thickness of the oxide layers, as shown in Figure $\mathbf{4}$ and $\mathbf{5}$. At $500{ }^{\circ} \mathrm{C}$, we can clearly see that the oxide layer consists of two oxide layers (Figure 4a and $\mathbf{4 b}$ ). The inner layer still contains carbides in the case of HTCS-130 and W600; these are Mo and $\mathrm{W}$ carbides (M6C, M2C and MC). The outer layer is porous (Figure $\mathbf{4 a}$ and $\mathbf{4 b}$ ). As we can see, Figure 4c (RavnexHD), has a thin oxide layer that is barely visible, while Dievar has no visible oxide layer and could not be measured (Figure 4d).

The oxide layers that formed during oxidation at $700{ }^{\circ} \mathrm{C}$ are visible in Figure 5. The oxide layers formed at $700{ }^{\circ} \mathrm{C}$ are thicker than at $500{ }^{\circ} \mathrm{C}$, as expected from the TG results. The average thicknesses of the oxide layers are presented in Table 3 . The structure of the

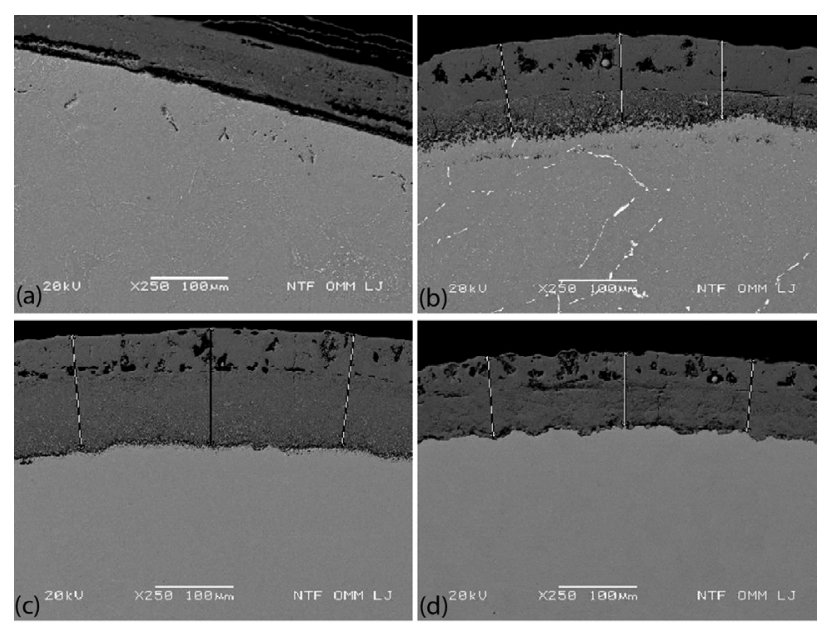

Figure 5: Thickness of the oxide layer at $700{ }^{\circ} \mathrm{C}$ of a) HTCS-130, b) W600, c) RavnexHD and d) Dievar 
samples' oxide layers at $700{ }^{\circ} \mathrm{C}$ is almost the same as at $500{ }^{\circ} \mathrm{C}$. The only difference is the thickness, i.e., the oxide layer is thicker at $700{ }^{\circ} \mathrm{C}$. The outer layer gets more porous at $700{ }^{\circ} \mathrm{C}$ (Figure 5).

There are two oxide layers, which is most evident in Figure 5b. The inner oxide layer still has some undissolved carbides. However, there are fewer carbides in the inner oxide layer at $700{ }^{\circ} \mathrm{C}$ than at $500{ }^{\circ} \mathrm{C}$.

Table 3: Average thickness of oxide layer for all investigated steels

\begin{tabular}{|l|c|c|}
\hline \multicolumn{1}{|c|}{ Steel } & $\begin{array}{c}\text { Average thickness of } \\
\text { the oxide layer at } \\
500{ }^{\circ} \mathrm{C}(\mu \mathrm{m})\end{array}$ & $\begin{array}{c}\text { Average thickness of } \\
\text { the oxide layer at } \\
700{ }^{\circ} \mathrm{C}(\mu \mathrm{m})\end{array}$ \\
\hline HTCS-130 & 8.01 & 26.3 \\
\hline W600 & 10.68 & 120.0 \\
\hline RavnexHD & 0.53 & 144.0 \\
\hline Dievar & $/$ & 97.0 \\
\hline
\end{tabular}

We analyzed the chemical composition of the oxide layers with EDS. The results show that the outer layer in all the analyzed samples consists of iron and oxygen at $500{ }^{\circ} \mathrm{C}$, while at $700{ }^{\circ} \mathrm{C}$ we also noticed some other chemical elements. These are alloying elements with the highest $w / \%$ in steels. Mo and $\mathrm{W}$ were found in the HTCS-130 and W600 outer oxide layer. Dievar and RavnexHD also have some $\mathrm{Mn}$ in the outer layer at $700{ }^{\circ} \mathrm{C}$; this is consistent with $\mathrm{MnO} . \mathrm{Cr}_{2} \mathrm{O}_{3}$ formation. ${ }^{23}$ On the other hand, the inner layers were slightly more complex; they contained more alloying elements than the outer layers (Table 4 and Table 5). In the case of HTCS-130 and $\mathrm{W} 600$ (at $500{ }^{\circ} \mathrm{C}$ and $700{ }^{\circ} \mathrm{C}$ ) Mo and $\mathrm{W}$ were detected; however, in the oxide layer of W600 we also detected some Ni. On the other hand, in the inner oxide layer of RavnexHD we detected $\mathrm{Cr}, \mathrm{Mo}, \mathrm{V}, \mathrm{Ni}, \mathrm{Si}$, and Mn. Dievar had Cr, Mo, V, Si and Mn in the inner oxide layer. This was expected, because those are the main alloying elements. The results of the EDS analyses of the Dievar steel at $500{ }^{\circ} \mathrm{C}$ are not presented (Table 4), because there was no oxide layer to analyze.

Table 4: EDS results of the inner oxide layer of the investigated steels after high-temperature oxidation at $500{ }^{\circ} \mathrm{C}$ in mass fractions

\begin{tabular}{|l|c|c|c|c|c|c|c|c|c|}
\hline \multirow{2}{*}{ Steel } & \multicolumn{10}{|c|}{ Chemical elements } \\
\cline { 2 - 10 } & O & Fe & Mo & W & Ni & Si & V & Cr & Mn \\
\hline HTCS-130 & 3.10 & 86.71 & 6.52 & 3.67 & $/$ & $/$ & $/$ & $/$ & $/$ \\
\hline W600 & 3.42 & 89.80 & 3.84 & 2.38 & 0.56 & $/$ & $/$ & $/$ & $/$ \\
\hline RavnexHD & 3.90 & 85.91 & 1.51 & $/$ & 0.99 & 0.47 & 1.30 & 5.54 & 0.38 \\
\hline
\end{tabular}

Table 5: EDS results of inner oxide layer of investigated steels after high temperature oxidation at $700{ }^{\circ} \mathrm{C}$ in mass fractions

\begin{tabular}{|l|c|c|c|c|c|c|c|c|c|}
\hline \multirow{2}{*}{\multicolumn{1}{|c|}{ Steel }} & \multicolumn{10}{|c|}{ Chemical elements } \\
\cline { 2 - 10 } & O & Fe & Mo & W & Ni & Si & V & Cr & Mn \\
\hline HTCS-130 & 3.98 & 74.35 & 16.91 & 4.60 & $/$ & $/$ & $/$ & 0.16 & $/$ \\
\hline W600 & 4.035 & 84.575 & 6.35 & 3.99 & 0.69 & $/$ & $/$ & 0.21 & 0.15 \\
\hline RavnexHD & 2.605 & 85.585 & 2.32 & $/$ & 1.92 & 0.47 & 0.73 & 6.14 & 0.23 \\
\hline Dievar & 2.79 & 89.23 & 2.12 & $/$ & $/$ & 0.31 & 0.53 & 4.81 & 0.21 \\
\hline
\end{tabular}

\subsection{X-ray diffraction results}

The oxide scales formed on the investigated hot-work tool steels were analyzed by XRD. At $500{ }^{\circ} \mathrm{C}$ Dievar has the thinnest oxide layer (Table 3), which is why the diffraction peak of the matrix $\left(\alpha_{\mathrm{Fe}}\right)$ is the most intensive (Figure 6). RavnexHD has a less intense diffraction peak of the matrix than Dievar (Figure 6), because it has a thicker oxide layer. W600 has a relatively thick oxide layer, so the matrix $\left(\alpha_{\mathrm{Fe}}\right)$ diffraction peak is even less intensive (Figure 6). The diffraction-peak intensities are consistent with the temperature of the high-temperature oxidation. HTCS-130 has a similar trend to W600:

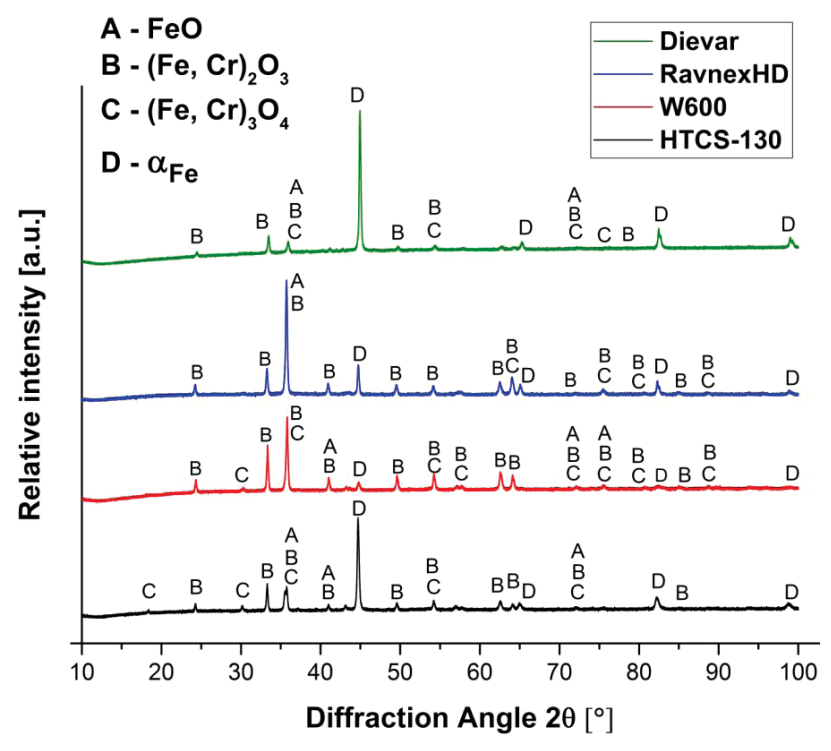

Figure 6: XRD patterns of the samples after oxidation at $500{ }^{\circ} \mathrm{C}$
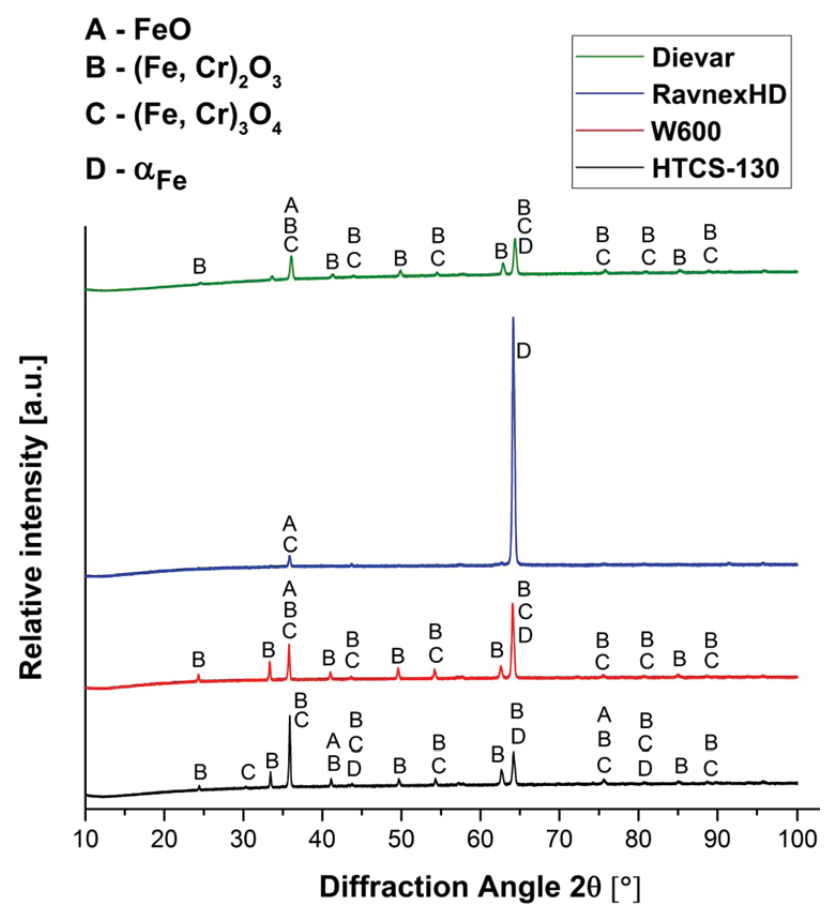

Figure 7: XRD patterns of the samples after oxidation at $700{ }^{\circ} \mathrm{C}$ 
hematite dominates, followed by magnetite and wüstite (Figure 6). Hematite $\left(\mathrm{Fe}_{2} \mathrm{O}_{3}-\mathrm{B}\right.$ in Figure 6) predominates, but we also notice some magnetite $\left(\mathrm{Fe}_{3} \mathrm{O}_{4}-\mathrm{C}\right.$ in Figure 6), and there are also beginnings of wüstite ( $\mathrm{FeO}$ - A in Figure 6) formation in Ravnex HD and Dievar.

At higher temperatures, $700{ }^{\circ} \mathrm{C}$ (Figure 7), we are closer to establishing the thermodynamic equilibrium of wüstite; more $\mathrm{FeO}$ (A in Figure 7) is present at elevated temperatures. HTCS-130 still has a lot of hematite (Figure 7), followed up by magnetite and wüstite. On the other hand, Dievar has less magnetite, hematite and almost no wüstite (Figure 7). W600 has also very little wüstite, hematite is still dominating, followed by magnetite (Figure 7). In comparison to other samples, RavnexHD has the thickest oxide layer, but the XRD result shows only magnetite and wüstite in the oxide layer (Figure 7).

If we compare the results at $500{ }^{\circ} \mathrm{C}$ and $700{ }^{\circ} \mathrm{C}$, we notice that there are a few changes in the oxide types, because the stabilities of the oxide phases $\left(\mathrm{FeO}, \mathrm{Fe}_{2} \mathrm{O}_{3}\right.$ and $\mathrm{Fe}_{3} \mathrm{O}_{4}$ ) are functions of the oxidation temperature and the ambient oxygen partial pressure. Wüstite should be stable above $570^{\circ} \mathrm{C}$ in air; however, it has been found in thin films down to $400{ }^{\circ} \mathrm{C} .{ }^{23}$ In our case we found wüstite at $500{ }^{\circ} \mathrm{C}$ (Figure 6). There is a strong relationship between the Fe (in our case hot-work tool steel) surface and the composition and thickness of the initial oxide. The first oxide that starts to form consists of $\mathrm{Fe}_{2} \mathrm{O}_{3}$ and $\mathrm{Fe}_{3} \mathrm{O}_{4}$, growth follows the parabolic kinetics, where the rate is dominated by the diffusional transport of $\mathrm{Fe}^{2+}$ and $\mathrm{Fe}^{3+}$ ions through the oxide grain boundaries. At temperatures below $500{ }^{\circ} \mathrm{C}$ the $\mathrm{Fe}_{3} \mathrm{O}_{4}$ nucleates first, followed up by $\mathrm{Fe}_{2} \mathrm{O}_{3}$, which nucleates on the $\mathrm{Fe}_{3} \mathrm{O}_{4}$. In addition, the oxidation of iron/steel often shows an unusual dependence on the oxygen pressure. ${ }^{23}$ These are the reasons why we have mostly hematite $\left(\mathrm{Fe}_{2} \mathrm{O}_{3}\right)$ and magnetite $\left(\mathrm{Fe}_{3} \mathrm{O}_{4}\right)$ in our investigate oxide layers (Figure 6 and Figure 7).

\section{CONCLUSIONS}

The following conclusions can be drawn from the paper. At $500{ }^{\circ} \mathrm{C}$ Dievar was the most oxidation-resistant steel, followed by RavnexHD, HTCS-130 and W600. The reason for the good high-temperature oxidation resistance of Dievar and RavnexHD is the high $\mathrm{Cr}$ content; it forms a protective $\mathrm{Cr}_{2} \mathrm{O}_{3}$ layer. At $700{ }^{\circ} \mathrm{C}$ HTCS-130 was the most oxidation-resistant steel, followed by Dievar, W600 and RavnexHD. The main reason for the very good oxidation resistance of HTCS-130 in comparison to the other steels is the ratio between the alloying elements and the high content of Mo, which improves the oxidation resistance. W600 has almost the same chemical composition as HTCS-130, but it seems that higher contents of $\mathrm{Ni}, \mathrm{Si}$ and $\mathrm{Mn}$ decrease the oxidation resistance in this case.

\section{Acknowledgement}

The European Regional Development Fund and the Ministry of Education, Science and Sport of the Republic of Slovenia financially support this work within the program MARTINA.

\section{REFERENCES}

${ }^{1}$ G. Roberts, G. Krauss, R. Kennedy, Tool Steels, $5^{\text {th }}$ ed., ASM, Ohio USA 1998, 364

${ }^{2}$ R. Y. Chen, W. Y. D. Yuen, Review of the high-temperature oxidation of iron and carbon steels in air or oxygen, Oxidation of Metals, 59 (2003) 5-6, 433-468, doi:10.1023/A:1023685905159

${ }^{3}$ M. H. Davies, M. T. Simnad, C. E. Birchenall, On the mechanism and kinetics of the scaling of iron, C.E. JOM, 3 (1951), 889-896, doi:10.1007/BF03397397

${ }^{4}$ J. B. Newkirk, High-temperature materials coatings and surface interactions, Freund Publishing House, Israel 1980, 314

${ }^{5}$ L. Vehovar, Korozija kovin in korozijsko preskušanje, Ljubljana 1991, 48

${ }^{6}$ L. Huabing, Z. Binbin, J. Zhouhua, Z. Shucai, F. Hao, H. Peide, D. Nan, Z. Wei, L. Guoping, F. Guangwei, L. Qizeng, A new insight into high-temperature oxidation mechanism of super-austenitic stainless steel S32654 in air, Journal of Alloys and Compounds, 686 (2016), 326-338, doi:10.1016/j.jallcom.2016.06.023

${ }^{7}$ S. Heino, B. Karlsson, Cyclic deformation and fatigue behaviour of $7 \mathrm{Mo}-0.5 \mathrm{~N}$ superaustenitic stainless steel-stress-strain relations and fatigue life, Acta Materialia, 49 (2001) 2, 339-351, doi:10.1016/ S1359-6454(00)00200-7

${ }^{8}$ E. X. Pu, W. J. Zhang, J. Z. Xiang, Z. G. Song, J. Li, Hot deformation characteristic and processing map of superaustenitic stainless steel S32654, Material Science and Engineering: A, 598 (2014), 174-182, doi:10.1016/j.msea.2014.01.027

${ }^{9}$ G. V. Prasad Reddy, R. Sandhya, S. Sankaran, P. Parameswaran, K. Laha, Creep-fatigue interaction behavior of 316LN austenitic stainless steel with varying nitrogen content, Materials \& Design, 88 (2015), 972-982, doi:10.1016/j.matdes.2015.09.007

${ }^{10}$ F. J. Perez, E. Otero, M. P. Hierro, C. Gomez, F. Pedraza, J. L. de Segovia, E. Roman, High temperature corrosion protection of austenitic AISI 304 stainless steel by $\mathrm{Si}$, Mo and Ce ion implantation, Surface and Coatings Technology, (1998) 108-109, 127-131, doi:10.1016/S0257-8972(98)00685-9

${ }^{11}$ V. Behrani, A. J. Thom, M. J. Kramer, M. Akinc, Microstructure and oxidation behavior of Nb-Mo-Si-B alloys, Intermetallics, 14 (2006) 1, 24-32, doi:10.1016/j.intermet.2005.03.007

${ }^{12}$ P. K. Ray, M. Akinc, M. J. Kramer, Formation of multilayered scale during the oxidation of NiAl-Mo alloy, Applied Surface Science, 301 (2014), 107-111, doi:10.1016/j.apsusc.2014.01.148

${ }^{13}$ Y. Liu, C. Yang, F. Chai, T. Pan, H. Su, High temperature oxidation resistance of $9 \mathrm{Ni}$ steel, Journal of iron and steel research, International, 21 (2014) 10, 956-963, doi:10.1016/S1006-706X(14) 60168-0

${ }^{14}$ C. K. Syn, B. Fultz, J. W. Morris, Jr., Mechanical stability of retained austenite in tempered $9 \mathrm{Ni}$ steel, Metallurgical and Materials Transactions A, 9 (1978) 11, 1635-1640, doi:10.1007/ BF02661946

${ }^{15}$ J. R. Strife, D. E. Passoja, The effect of heat treatment on microstructure and cryogenic fracture properties in $5 \mathrm{Ni}$ and $9 \mathrm{Ni}$ steel, Metallurgical Transactions A, 11 (1980) 8, 1341-1350, doi:10.1007/ BF02653488

${ }^{16}$ B. Fultz, J. I. Kim, Y. H. Kim, H. J. Kim, G. O. Fior, J. W. Morris, The stability of precipitated austenite and the toughness of $9 \mathrm{Ni}$ steel, Metallurgical Transactions A, 16 (1985) 12, 2237-2249, doi:10.1007/BF02670423 
${ }^{17}$ T. Fukagawa, H. Okada, Y. Maegara, Mechanism of red scale defects formation in Si-added hot-rolled steel sheets, ISIJ International, 34 (1994) 11, 906-911, doi:10.2355/isijinternational.34.906

${ }^{18}$ L. Yin, S. Balaji, S. Sridhar, Effects of nickel on the oxide/metal interface morphology and oxidation rate during high-temperature oxidation of $\mathrm{Fe}-\mathrm{Cu}-\mathrm{Ni}$ alloys, Metallurgical and Materials Transactions B, 41 (2010) 3, 598-611, doi:10.1007/s11663-009-9334-z

${ }^{19}$ E. J. Song, D. W. Suh, H. K. D. H. Bhadeshia, Oxidation of silicon containing steel, Ironmaking \& Steelmaking, 39 (2012) 8, 599-604, doi:10.1179/1743281212Y.0000000007

${ }^{20}$ X. Jin, S. Chen, L. Rong, Effects of Mn on the mechanical properties and high temperature oxidation of $9 \mathrm{Cr} 2 \mathrm{WVTa}$ steel, Journal of
Nuclear Materials, 494 (2017), 103-113, doi:10.1016/j.jnucmat. 2017.07.024

${ }^{21}$ A. Col, V. Parry, C. Pascal, Oxidation of a Fe-18Cr-8Ni austenitic stainless steel at $850{ }^{\circ} \mathrm{C}$ in $\mathrm{O} 2$ : Microstructure evolution during breakaway oxidation, Corrosion Science, 114 (2017), 17-27, doi:10.1016/j.corsci.2016.10.029

${ }^{22}$ S. S. Brenner, Oxidation of iron-molybdenum and nickel-molybdenum alloys, Journal of The Electrochemical Society, 102 (1955) 1, 7-15, doi:10.1149/1.2429990

${ }^{23}$ T. Richardson, Shreir's Corrosion, $1^{\text {st }}$ ed., Elsevier Science, 2009, 4000 